\title{
AStudy of Level of Aspiration Among The IX Grade Children OF Working AND Non-Working Mothers
}

Prof. (Dr.) Shubhada Pandey

Mewar University

Chittorgarh
Kavita Gupta

Mewar University

Chittorgarh

Email: kavita79g@gmail.com
Abstract

In the present study, the researcher tried to compare the two groups (children of working mothers and children of nonworking mothers) on the component of the level of aspiration. The sample for the proposed study was consisting of 500 children. In which 250 children of working mothers and 250 children of nonworking mothers. In her study, the researcher found the outcomes based on the study and concluded.

Keywords: Level of aspiration, working mothers, non-working mothers.
Reference to this paper should be made as follows:

Received: 27.05.2020

Approved: 29.06.2020

Prof. (Dr.)Shubhada Pandey Kavita Gupta

A STUDY OF LEVEL OF Aspiration AMONG THE IX

GRADE CHILDREN OF

WORKING AND NON-WORKING MOTHERS

RJPSSs 2020, Vol. XLVI,

No. 1, pp. 55-64 Article No.07

Online available at: http://rjpsss.anubooks.com/ https://doi.org/10.31995/

rjpsss.2020v46i01.07 
A Study of Level of Aspiration Among The IX Grade Children of Working and Non-Working Mothers Prof (Dr.) Shubhada Pandey, Kavita Gupta

\section{Introduction}

Children are citizens of tomorrow of the country who have an important role to play in leading the country on a progressive path. Thus parents must turn children into healthy and noble citizens. The child is not only the future of a nation and its aspirations but also its strength in reserve.

In this changing world to become economically self-dependent and to fulfill her aspiration, women are doing household as well as moving outside the home to earn money. Whether the dual role of the woman affects the values, adjustment academic achievement, and level of aspiration of her children.

Aspiration starts to be shaped early in a child's life but is modified by experiences and the environment. Aspiration tends to decline as children mature, in response to their growing understanding of the world and what is possible and to constraints imposed by previous choices and achievements. This decline particularly marked for those facing multiple barriers.

Children adopt the many qualities of the parents and become them as the role model. In the vice, versa parents have an impact on the children that creates many things like values, aspirations, etc. in the children.

The women's employment is increasing day by day approximately seventyfive percentages of mothers are working as a labor although most of them have very young children. Anxiety and stress symptoms are increasing in working women day by day. Working mothers experienced a high level of stress as compared to unemployed moms (Arieti, S. 1974). Work-family spillover may also occur due to having juggle multiple roles, \& may result when the pressures from work have an effect on one's attitude \& behavior within the family. According to Postpartum Support International, up to $10 \%$ of women develop an anxiety disorder \& stress. Working women face a high level of stress and anxiety as compared to unemployed women. The pressure of the work affect the one's attitude and behavior within the family.

Mothers may work in an office from nine to five or whatever may be .when mothers return home after completing their work, they are usually exhausted and do not get proper time to their family and children.

Working status of mothers has a great effect on the children's academic achievement, values, adjustment, and level of aspiration of children. The working status do not allow them to spend the whole day with their children. Therefore researcher thought to make a study on these parameters as and how the things are affected by the children's conditions, when their mothers are working and non-working.

P.R. Das (2003) made a study of the level of aspiration of a deprived and 
RJPSSs, Vol. XLVI No.1, June 2020 ISSN: (P)0048-7325 (e) 2454-7026 Impact Factor 7.821 (SJIF)

https://doi.org/10.31995/rjpsss.2020v46i01.07

non-deprived adolescent. The purpose of this study was to explore the level of aspiration with the purpose of counseling deprived and non-deprived adolescents. A sample of 120 boys and girls of 12-18 years selected on the basis of a prolonged deprivation scale. The findings of the study are:

1. The deprived and non-deprived group differs significantly regarding the level of aspiration. Nondeprived group aspired higher than the deprived group.

2. Boys of both the group differ significantly regarding the level of aspiration.

3. Girls of both the group do not differ significantly regarding the level of aspiration.

Though increasing non-deprived girls is 19.0 which is higher than the mean of deprived girls but there is no significant different

There was no significant difference between boys and girls but mean values of boys and girls but the mean values of boys were higher than girls of the nondeprived group.

Parveen and Barkat (2004) made a study on the level of aspiration of academically successful and unsuccessful students. The sample consisted of 50 academically successful students in senior secondary school and 50 academically unsuccessful student's failure in the SSC exams. The age range of the students was between 16 to 19 years. It was observed that difference between that the group of students is found to be significant at 0.01 levels which indicates the academically successful students make significantly higher than the academically unsuccessful students.

MalvinderAhuja and sunitagoyal (2005) conducted a study on 100 adolescents studying in the $9^{\text {th }}$ grade of schools of Chandigarh. The findings were that there was no significant difference in the occupational Aspiration of adolescents belonging to the high and low parental involvement.

Annaraja and Mohanan (2006) studied the "Inter-relationship among academic achievement, study habits and level of Aspiration: A study on higher secondary students". Objectives of the study were to find out whether there is any significant difference between female and male students in academic achievement, study habits and level of aspiration, to find out whether there is any significant difference between private and government school students study habits and level of aspiration and to find out whether there are any significance and relationship among academic achievement, study habits and level of aspiration. The study used a stratified random sampling technique to select a sample of 211 students (109 females and 102males). The data for the study has been collected using three tools, namely, 
A Study of Level of Aspiration Among The IX Grade Children of Working and Non-Working Mothers Prof (Dr.) Shubhada Pandey, Kavita Gupta

i) Personal Information Schedule ii) Level of aspiration scale developed by Sananda Raj, AnnarajaandMohanan (2001) and iii) Study habits Inventory developed by Sananda Raj andAnnaraja (2001). The statistical techniques used for analyzing the data weren't' test for large independent samples, and Pearson's product-moment correlation. The major findings of the study were there is a significant difference between the female and male students in academic achievement, study habits, and level of aspiration. The female students have high academic achievement, study habits, and level of aspiration compared to the male students. There exists a significant difference between private and government school students in academic achievement, study habits, and level of aspiration. The private school students have high academic achievement, study habits, and level of aspiration compared to the government school students. There exists a significant and positive correlation among academic achievement, study habits, and level of aspiration. There is a substantial or marked correlation between academic achievement and level of aspiration. There is a substantial or marked correlation between study habits and academic achievement.

Ms. Moomin Jan (2015), Research Scholar, Faculty of Education, University of Kashmir, Srinagar, J\&Kchildrn. The sample of 100 children consisting of 50 each of working and nonworking mothers was taken from many senior secondary schools of District Anantnag. She used the inventory of Dr. Mahesh Bhargava and Prof. M.A. Level of aspiration means an individual's future expectations or ambitions for her study. The findings of the study revealed that children of working mothers are personally determinant, well environment determinants, and high in level of aspiration as compared to children of non - working mothers.

Dr. Kounsar Jan (2016), Assistant Professor, Institute of Education, University of Kashmir, made a Study on the Level of Educational Aspiration between the Children of Working and Non-Working Mothers. This study was based on various components of the level of aspiration. The sample consisting of 50 children each of working mothers and non-working mothers was taken from secondary schools situated in Kashmir, J\&K. She used inventory prepared by Dr. Mahesh Bhargava and Prof. M.A. Level of aspiration an individual's future expectations or ambitions. The results showed a significant difference and found the children of non-working mothers are higher in the level of aspiration. The following outcomes were found:

1. There is a significant difference between children of working and non-working mothers on the personal determinants dimension of the level of aspiration. However, the mean favors children of non-working mothers. That implies the children of working mothers are personally determinant as compared to children of working mothers. 
RJPSSs, Vol. XLVI No.1, June 2020 ISSN: (P)0048-7325 (e) 2454-7026 Impact Factor 7.821 (SJIF)

https://doi.org/10.31995/rjpsss.2020v46i01.07

2. There is a significant difference between the two groups with respect to the environment determinants dimension of the level of aspiration and found children of working mothers are well environment determinants as compared to children of non-working mothers.

3. The study found that the children of non-working mothers are higher in the level of an aspiration than the children of working mothers.

\section{Definition of the terms used}

\section{Level of aspiration}

"The level of future performance in a familiar task which an individual knowing his level of past performance is that task explicitly undertakes to reach."

\section{Working Women}

A working woman refers to a woman who works outside her home for a wage or salary and contribute family income. They are engaged in different vocations as education, teaching, nursing, administration, factories, etc. Women are compelled to leave the security of their homes due to economic necessity and hence they do not have enough time to look after their children.

\section{Non-working Women}

A woman who spends her time at home and look after their children and family and may or may not be financially independent. They have no contribution to the family income.

\section{Objectives}

1. To study the level of aspiration among the IX grade children of working and non -working mothers.

2. To compare the level of aspiration among the IX grade children of working and non -working mothers.

\section{Hypothesis}

1. There is no significant difference in the level of aspiration between the children of working mothers and children of non- working mothers.

2. There is no significant difference in the level of aspiration between the male children of working mothers and male children of non -working mothers.

3. There is no significant difference in the level of aspiration between the female children of working mothers and female children of non -working mothers.

\section{Research methodology}

Method of research is sometimes determined by the theory of the topic 
A Study of Level of Aspiration Among The IX Grade Children of Working and Non-Working Mothers Prof (Dr.) Shubhada Pandey, Kavita Gupta

under study objectives of the study and resources of the investigator. These considerations have led investigators to use the descriptive survey method. In the present investigator, all the steps and characteristics have been used which are essential for the descriptive research.

\section{Population and sample}

The entire male and female students of the $9^{\text {th }}$ class were the populations for the current study of the selected schools in Ghaziabad district and the sample was selected with the help of the non-probability method. It was not possible to consider all the senior secondary schools of the Ghaziabad district so researchers used to the random sampling method to select the schools.

First, the researcher made the list of all the senior secondary schools in Ghaziabad district than the researcher selected the name of the school by a lottery system and then visited to those schools to collect the data.

For this study, the researcher collected the data from the 500 students including male and female students of the selected schools.

\section{Tools used}

The data for the present study was collected with the help of Dr. Mahesh Bhargawa and prof.M.A ShahLevel of aspiration means an individual's future expectations or ambition for conclusion the result. Researcher used the standard errors and' test to draw the inferences.

\section{Result analysis and findings}

Table 1

There is no significant difference in the level of aspiration between the children of working mothers and children of non-working mothers.

\begin{tabular}{|l|l|l|l|l|l|}
\hline Group & Sample size & Mean & S.D. & S.E.D. 't' value \\
\hline Children of working mothers & 250 & 3.72 & 2.02 & & \multirow{2}{*}{0.13} \\
\hline $\begin{array}{l}\text { Children of non- } \\
\text { working mothers }\end{array}$ & 250 & 3.76 & 2.09 & $0.35^{* *}$ \\
\hline
\end{tabular}

** Non-significant at 0.01 level of significance 


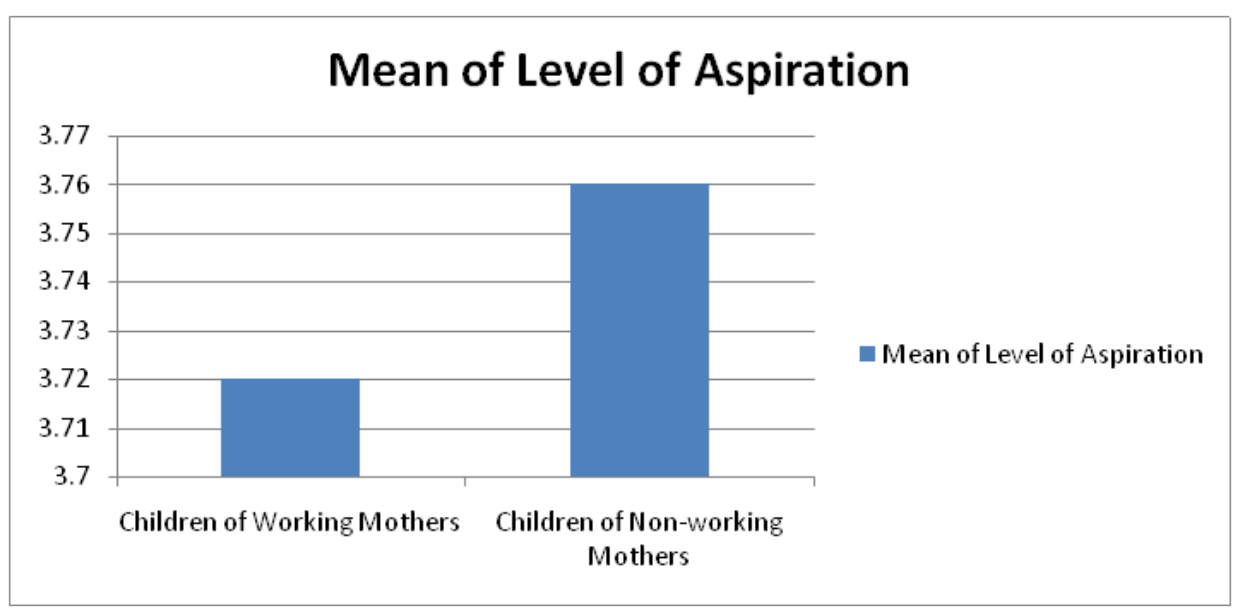

Mean of Level of Aspiration in the Children of Working Mothers and Nonworking mothers

The above result of mean, S.D., and t-value of the children of working mothers and the children of non-working mothers indicates that there is no significant difference between the children of working mothers and the children of non- working mothers with respect to the level of aspiration. The mean scores of children of working mothers and Children of non-working mothers are 3.72 and 3.76 respectively. The ' $t$ ' value is 0.35 , not significant at 0.05 level of significance. Hence the hypothesis is accepted.

\section{Table 2}

There is no significant difference in the level of aspiration between the male children of working mothers and the male children of non-working mothers.

\begin{tabular}{|c|c|c|c|c|c|}
\hline Group & Sample size & Mean & S.D. & SE.D. & 't' value \\
\cline { 1 - 4 } $\begin{array}{c}\text { Male children of } \\
\text { working mothers }\end{array}$ & 250 & 3.64 & 1.96 & \multirow{2}{*}{0.18} & \multirow{2}{*}{$0.84 * *$} \\
\cline { 1 - 4 } $\begin{array}{c}\text { M ale children of non- } \\
\text { working mothers }\end{array}$ & 250 & 3.79 & 1.96 & & \\
\hline
\end{tabular}

** Non-significant at 0.01 level of significance 
A Study of Level of Aspiration Among The IX Grade Children of Working and Non-Working Mothers Prof (Dr.) Shubhada Pandey, Kavita Gupta

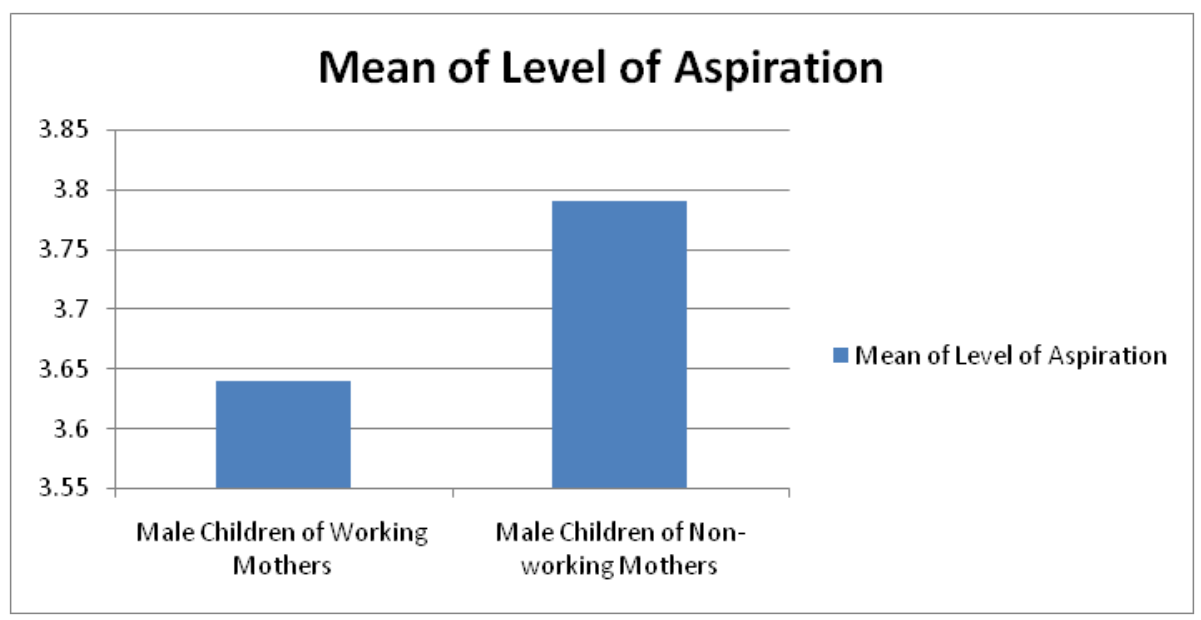

Mean of Level of Aspiration in the Male Children of Working Mothers and Non-working Mothers

On comparing the male children of working mothers and male children of non-working mothers, we found the Mean, S.D., and t-value scores. The mean scores of male Children of working mothers and children of non-working mothers are 3.64 and 3.79 respectively The ' $t$ ' value is 0.84 which is not significant at 0.05 level of significance. This shows that there is no significant difference in the level of aspiration between the male children of working mothers and the male children of non-working mothers. Hence the hypothesis is accepted.

\section{Table 3}

Study of level of aspiration between the female children of working mothers and female children of non- working mothers

\begin{tabular}{c|c|c|c|c|c|}
\hline Group & Sample size & Mean & S.D. & SE.D. & 't' value \\
\hline $\begin{array}{c}\text { Female children of working } \\
\text { mothers }\end{array}$ & 250 & 3.80 & 2.08 & 0.19 & $0.32^{* *}$ \\
\cline { 1 - 4 } $\begin{array}{c}\text { Female children of non-working } \\
\text { mothers }\end{array}$ & 250 & 3.74 & 2.13 & & \\
\hline
\end{tabular}

** Non-significant at 0.01 level of significance 


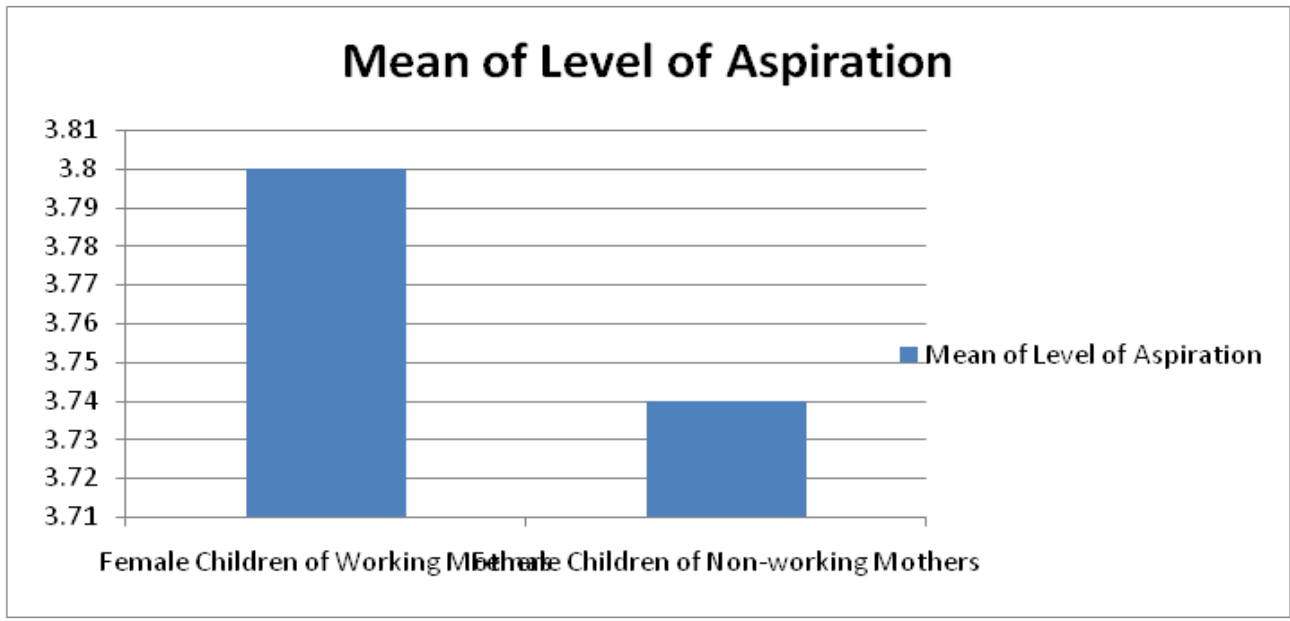

\section{Mean of Level of Aspiration in the Female Children of Working Mothers and Non-working Mothers}

The score of female children of working mothers and the female children of non-working mothers, the ' $t$ ' value was found to be 0.32 , not significant at 0.05 level of significance. Hence there is no significant difference between the female children of working mothers and the female children of non-working mothers with respect to the level of aspiration. Thus the hypothesis is accepted.

The mean scores of female children of working mothers and female children of non-working mothers are 3.80 and 3.74 respectively the $t$ value is 0.32 which is not significant at 0.05 level of significance hence showing no significant difference between the female children of the working mothers and the female children of the non-working mothers.

\section{Conclusion}

The researcher was conducted to study the level of aspiration of the children of the working and non-working mothers.Researcher reached the following conclusion-

1. The children of working mothers and the children of non-working mothers indicate no significant difference with respect to the level of aspiration. The mean scores of children of working mothers and Children of non-working mothers are found to be very closer to each other.

2. On comparing the level of aspiration in between the male children of working mothers and male children of non-working mothers, we found their mean scores are 3.64 and 3.79 respectively. the ' $t$ ' value was not significant at 
A Study of Level of Aspiration Among The IX Grade Children of Working and Non-Working Mothers Prof (Dr.) Shubhada Pandey, Kavita Gupta

0.05 level of significance. This shows that there is no significant difference in the level of aspiration between the male children of working mothers and the male children of non-working mothers.

3. The score of female children of working mothers and the female children of non-working mothers, the ' $\mathrm{t}$ ' value was found to be not significant at 0.05 level of significance. Hence there is no significant difference between these two groups with respect to the level of aspiration. The mean scores of female children of working mothers and female children of non-working mothers are 3.80 and 3.74 respectively; it indicates the almost equal level of aspirations

\section{Reference}

1 Ahuja M. and Goel S. (2005); "A study and Achievement and Aspiration of an adolescent in relation to parental involvement", Indian journal of applied psychology 2005, vol 42, p.p. 19-126

2 Annaraja, P., Sam Sananda Raj, H., and Mohanan, A. (2006). Inter-relationship among academic achievement, study habits, and level of Aspirations: A study on higher secondary students. Research and Reflection on Education 4(2), pp: 2-4

3 Das P.R. 2003; "A study of study of Aspiration of Deprived and Non-Deprived Adolescents", Indian psychological review vol. 60, the Year 2003 P.P.- 52-56

4 Jan, K. (2016); “ The level of Educational Aspiration of the Children of Working and Nonworking mothers", International Journal of Scientific Research and education, ISSN 2321-7545, Volume 4, Issue 02, Pages 4910-4913.

5 MsMooman Jan (2015); "A Study of the level of Educational Aspiration of the Children of Working and Non-working mothers", Oct-Nov 2015, Vol.2/12 www.srjis.com Page (3017-3023).

6 Praveen and Barkat (2004); "Level of Aspiration and Academically successful and unsuccessful students", Vol 35, P.P.: 51-54. 